\begin{tabular}{|c|c|c|}
\hline Beitr. Ent. & Keltern & ISSN 0005-805X \\
\hline $\mathbf{6 2}(2012) 2$ & S. $459-465$ & 20.12 .2012 \\
\hline
\end{tabular}

\title{
Index Novus Litteraturae Entomologicae
}

\author{
With 4 figures
}

ECKHARD K. GROLL

\section{Summary}

The "Index Novus Litteraturae Entomologicae", a completely revised new edition of the "Index Litteraturae Entomologicae: Serie I : Die Welt-Literatur über die gesamte Entomologie bis inclusive 1863” (HorN \& SCHenkLING 1928-1929) has been published by the Senckenberg Deutsches Entomologisches Institut (SDEI) in Müncheberg. This bibliography of the literature on entomology from the beginning until 1863 is now available in the Internet (http://sdei.senckenberg.de/index) as an online database free of charge.

The history of work on the new edition, the scope of the necessary research and the essential features of the database application are presented.

\section{Zusammenfassung}

Der "Index Novus Litteraturae Entomologicae", eine komplett überarbeitete Neuauflage des "Index Litteraturae Entomologicae : Serie I : Die Welt-Literatur über die gesamte Entomologie bis inclusive 1863" (Horn \& SCHENkLing 1928-1929) wurde vom Senckenberg Deutschen Entomologischen Institut (SDEI) in Müncheberg herausgegeben. Die Bibliographie ist jetzt als Online-Datenbank kostenlos im Internet (http://sdei.senckenberg.de/index) verfügbar.

In der Arbeit werden die Geschichte der Bearbeitung der Neuauflage, der Umfang der notwendigen Recherchen und die wesentlichen Merkmale der Datenbankanwendung vorgestellt.

\section{Key words}

Bibliography, literature on Entomology, online database

\section{Introduction}

On October 22nd, 2012 the "Index Novus Litteraturae Entomologicae" was published by the Senckenberg Deutsches Entomologisches Institut (SDEI) as an online database in the Internet under http://sdei.senckenberg.de/index. This completely revised new edition replaces the "Index Litteraturae Entomologicae : Serie I : Die Welt-Literatur über die gesamte Entomologie bis inclusive 1863" published 1928-1929 by Walther Horn and Sigmund SCHENKLing (hereafter called Index I; Horn \& SCHENKLING 1928-1929).

\section{Material and Methods}

Work began on this new version in the mid-1990s. At that time, we at the institute pondered about the conceptual framework necessary to counteract the specific problem in taxonomy of repeatedly being obliged to access the literature that appeared up to 1758. Walther Horn wrote in the preface to the Index I: [translated from German] "Even the most modest attempt to create a 
classification is still based today on 3 historic prerequisites: genera, species, authors' names. Without the historical details of the original descriptions, the hitherto existing view is that no reliable work is imaginable; even past mistakes, in the form of synonymies, etc., would in future be perpetuated. Therefore we require a source of advice that guides us through the past, including its wrong turnings. He who denies this, will only create, for example, synonymy that causes universal misunderstanding and further confusion." (Horn \& SCHENKLING 1928-1929).

It was decided to capture the entire entomological literature until 1863 and the later bibliographic works that refer to this in a database and to publish this revised edition of the Index I. The year 1863 is insofar significant, in that with the "Zoological Record" a work exists that covers the essential bibliographic needs of the entomologist for literature that appeared after 1863. In addition, for the period from 1864 to 1900 , the series II of the Index (Derksen \& Scheiding 1963-1975) is available. Finally, a taxon-related bibliography up to 1850 is found in the excellent "Index Animalium" (SHerborn 1902, 1922-1933).

We have been confident of success not only because of the excellent conditions offered by the specialised entomological library of the institute in Müncheberg and the previous work of the institute since the 1920s, but also because of the rapid advances that have been made in computer technology, data basing, text editing and optical character recognition software. First experiences with relational databases were also available, based on the recording of the biographies of entomologists in the "Biographical Database" (Groll 2012) started some years earlier (Groll \& TAEger 1996).

It was initially planned to print the new edition in 5 volumes. Thus a bottleneck in the availability of entomological literature was to be eliminated, because both the "Bibliotheca Entomologica" (HAGEN 1862-1863) as well as the Index I are now only to be obtained in antiquarian bookstores.

However, since the Index I was printed, hundreds of corrections and additions, special bibliographies and databases have been issued, which cannot be ignored.

Therefore, the citations have been checked and corrected based on publications, such as the Opinions and Declarations of the International Commission of Zoological Nomenclature (ICZN) or based on data available in the Internet, such as the world's largest specialized database for serial titles of the Staatsbibliothek zu Berlin (ZDB-OPAC 2012). This approach guarantees the new work a value which far surpasses what would have been achieved by a mere facsimiledigitization of the Index I and the secondary publications. In most cases, a user of the revised bibliography needs no longer to repeat this laborious research. The list of literature used can be seen in the imprint of the online database.

In 1997, the database was generated using PARADOX and data input in the network by numerous staff began. But neither the network nor the database technology were able to cope with several parallel accesses. Therefore, data collection was essentially continued by Andreas Taeger, Reinhard Gaedike and Eckhard Groll. Also tested for its usability and later discarded was scanning of the pages of Index I and subsequent text recognition with Optical Character Recognition software. Although these technologies were still in their infancy, the biggest problem was the reading and interpretation of the original. To save print space, HoRn and SCHENKLING had strongly compressed all data. So, for example, the original data on the work of Cuvier "La Règne animal" published in several editions and several translations were contained in just 20 lines. Other editions and translations are therefore never chronologically arranged nor to be found under the names of their real authors. The entomological adaptations by other subsequent authors, such as LATREILlE or WeSTWOOD, are not consistently referenced. Furthermore, the dating of the first edition and the correction of the author MCMurTice was necessary (HorN \& Schenkling, 1928-1929, p. 230). Now the work mentioned above is represented in the database within four separate citations with four annotations and 22 bibliographic facts. 
Titles of all journals and some monographs in the Index I, hereafter called sources, are often so excessively abbreviated that they can hardly be recognized, e. g. "Epistol." or "Opusc. med.". Furthermore the dating of many works is incorrect. Especially works issued in parts are problematic.

Because of the coincidence of various inaccuracies some citations are completely unrecognisable. An extreme case is, for example Gleditsch, J. G. ... Abhandlung von Vertilgung der Zugheuschrecken und den eigentlichen Hülfsmitteln, die sich auf eine richtige Erkenntniss dieser Thiere gründen ... Act. Reg. Soc. Berol. 1752, p. 83-101, 4 Taf. (Fig. 1) turned out after the examination of the original to be correctly cited thus: GLeditsch, J. G. 1754: Des sauterelles d'Orient, qui voyagent en troupes, et qui ont fait des ravages dans la Marche de Brandebourg en 1750. - Histoire de l'Académie Royale des Sciences et des Belles-Lettres de Berlin, Berlin - (1752) 83-101, 4 Taf. Only the author and the page numbers remained from the original citation.

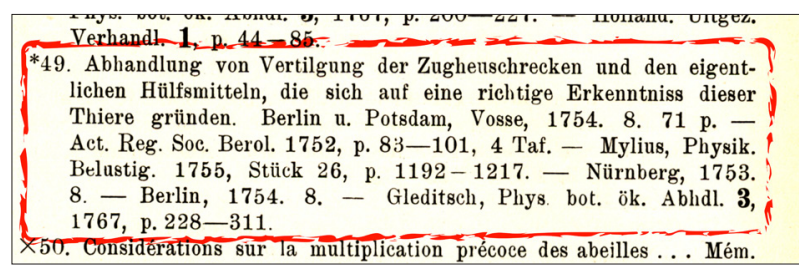

Fig. 1: Original citation \#7946 from page 431 in HorN \& SCHENKLING (1928-29).

Hence, during data recording the original texts had first to be split into individual citations, then supplemented, corrected and finally entered in a standardised way in the database. This step required a high level of library-related knowledge. Often, these citations had to be compared with the original or with secondary publications. Finally the resulting records were collated and cross-referenced.

Overall, the research required significantly more time than initially planned. The publishing history of almost all periodicals had to be established in the ZDB-OPAC and in the secondary literature. Only on the basis of this data (GAEDIKE 2005, unpublished) could the citation of the periodical articles be matched. For monographs, mostly only a comparison with the original in the libraries of London, Berlin, Munich, Greifswald and Eberswalde proved to be of use. On the other hand, it has increasingly been possible to refer to content available on the Internet, such as Google Books (2012) or Biodiversity Heritage Library (BHL 2012). Surprisingly, in this way were found numerous works listed neither in Hagen (1862-1863) nor in HorN \& ScHenkLING (1928-1929).

\section{Results}

As a result the online database is now available free of charge under the license "creative commons: BY-SA 3.0". This means that a user is free to copy, distribute and transmit the data contained in the work, to adapt these, and to make commercial use of the work, under the conditions that a user must attribute the work in the manner specified by the authors. A new work based on the database may be distributed only under the same or similar license conditions as apply to the latter (CC 2012).

The original 25,229 entries in Horn \& SCHENkLING (1928-1929) were increased to over 46,500. These additional data were created by the separation of the unduly condensed original entries or originated in secondary publications.

Originals of many works were checked, permitting clarification or correction of unclear or dubious citations. 


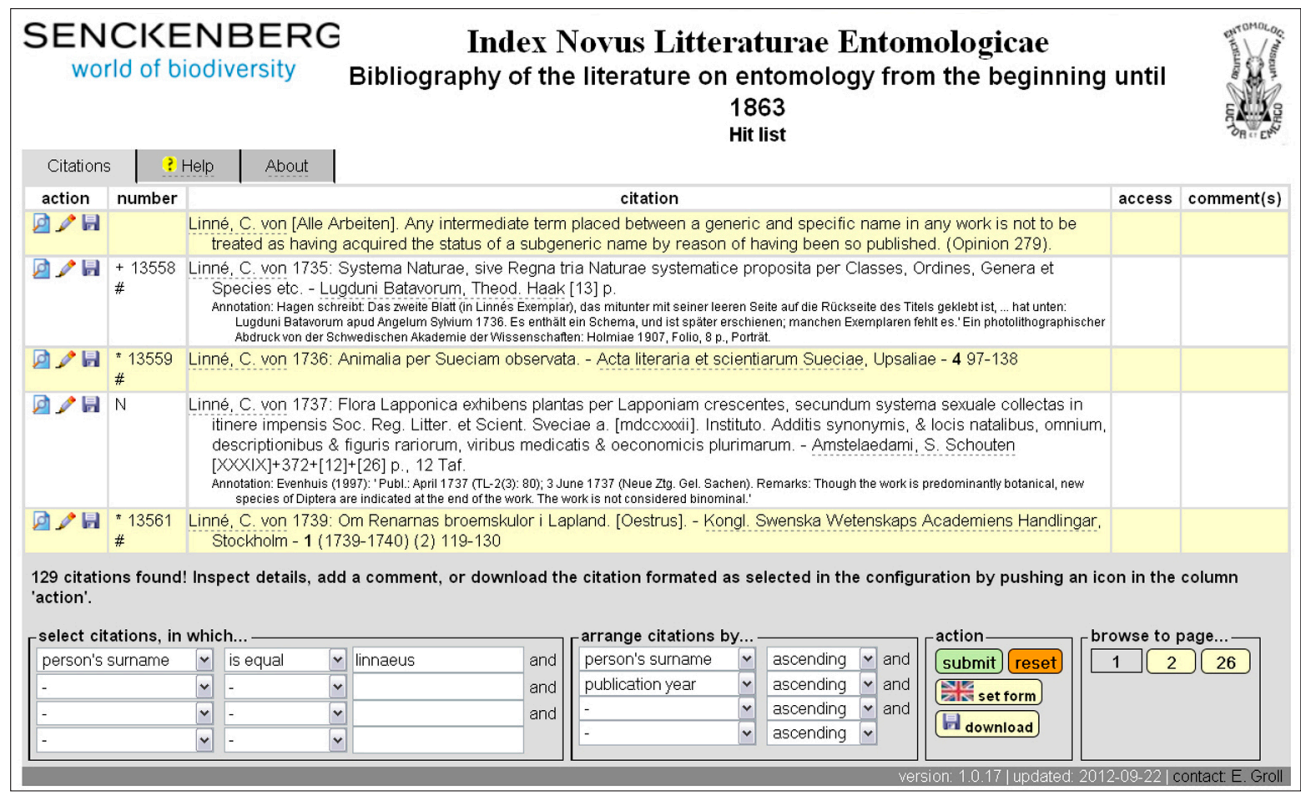

Fig. 2: Main page of the application with hit list and controls for selection, sorting and navigation.

The dating of the works was taken partly from the original work, partly from secondary literature that appeared later. The dates are thus often different to, or more accurate than those in HaGEN (1862-1863) or Horn \& Schenkling (1928-1929). In many such cases, nomenclatural consequences due to the new information on priority are expected!

All the names of authors, editors, artists, engravers, etc. are recorded together with their different spellings, synonyms and aliases in a separate database. This supports searches with various spellings of a name. Similar to the original Index I, biographical data on the persons are presented, and sometimes a portrait can be viewed by pop-up window (Fig. 3). This is made possible by linking the bibliography with the biographies of entomologists of the world and the photograph collection of the SDEI.

All names of sources are given in full and recorded together with alternative spellings in a separate database. This supports searching with abbreviations of the title. Comprehensive information on the sources, such as abbreviations, synonyms, publishing frequency, and chronology can be viewed in a pop-up window (Fig. 4).

All parts of works, other editions, addenda, translations, etc. are cross-referenced to a complete chronology and are listed in the detail mode.

Also visible in this mode are numerous bibliographical facts, references to other editions, translations, excerpts, notes on the dating, additions, corrections and many others.

For over 1,100 works with valuable illustrations the registration number in Nissen (1951) or (1966-1969) is given, the important bibliographical reference work that records the illustrated zoological and botanical books from antiquity to the 20th century.

To assist in accessing the publications that are available in the library of the SDEI in Müncheberg (B15), the corresponding shelf mark is recorded. This information can be used to order copies. 
Also indicated are rulings of the ICZN, when these affect the validity of taxonomic acts in certain publications (Official Lists and indexes of names and works in Zoology). The relevant opinions and declarations have been evaluated.

Originally, The Index Novus Litteraturae Entomologicae was to have appeared as a printed book, which would have suited the reading habits of some users and been advantageous for long-term archiving. On the other hand, the now available online database has indispensable features that a printed work cannot offer.

Multifaceted searches of the database can be made for personal names, publication years, words in the title, sources, or illustration information. Together with the sort function, different lists can be created, e. g. bibliographies of authors, tables of contents of journals or overviews of specific years. The results can be exported as plain text for word processors in Unicode or in bibliographic exchange formats. So far, the

BibTeX format for literature management programs, such as Zotero (Zotero 2012), Citavi ${ }^{\circledR}$ (Citavi 2012) or Endnote ${ }^{\circledR}$ (Endnote 2012) are offered. In addition, the intuitive user interface is multilingual (currently in English and German) and complemented by comprehensive help texts.

Finally, the user can comment on any citation and help to improve the database by providing additions and corrections. Perhaps we can say in a few years, like Horn (1934): [translated from German] „A year ago a completely new source of help became available, in that numerous entomologists declared themselves willing to check and complete the card indexes that we had prepared of their works. Indeed, still better, colleagues have agreed to act in this capacity as ombudsmen within the circle of their entomological acquaintances... The help that we have received in this way is of extraordinary value. We therefore appeal to all entomologists, worldwide, to assist us in a similar way".

The authors can only agree with these sentiments, and hope that with this online database they have provided a useful tool for entomologists, librarians and booksellers. 


\section{Acknowledgements}

The work would have been impossible without the diverse support of many colleagues. This support concerned especially the clarification of inconsistencies in the citation and dating of sources. Within the framework of lending between German libraries it was possible to loan and evaluate numerous journals and series. For the research necessary in this context and the rapid execution of these loans, Mrs Wehrens (DEI) is warmly thanked. Further libraries permitted on the spot research in their repositories, which was particularly time-saving. At this point we wish to thank those responsible in the Berlin State Library, the University Library of Greifswald and the library of the University for Sustainable Development in Eberswalde. Many sources could be evaluated in the library of the Museum für Naturkunde of the Humboldt Universität in Berlin in the repositories, which was possible only through the friendly support of Dr Muggelberg, Mrs Rißberger and Mr Raake. We were given important items of information by Dr J. Diller (library of the Zoologische Staatssammlung München). Dr M. Nuß researched for us in the library of the Natural History Museum, London. Special thanks go to Mr N. L. Evenhuis from Bishop Museum, Honolulu for making available his at that time unpublished results on the dating of various journals. Last but not least we thank all colleagues of the SDEI, especially Mrs C. Grunow and Mr A. Liston, who helped with remarks, corrections, and translations.

\section{References}

BHL 2012: Biodiversity Heritage Library. URL: http://www.biodiversitylibrary.org/ (10.10.2012).

CC 2012: Creative Commons. URL: http://creativecommons.org (10.10.2012).

Citavi 2012: Citavi ${ }^{\circledR}$ Literaturverwaltung und Wissensorganisation - Swiss Academic Software. URL: http://www.citavi.com/de/index.html (10.10.2012).

Derksen, W. \& Scheiding, U. 1963-1975: Index Litteraturae Entomologicae. Serie II: Die Welt-Literatur über die gesamte Entomologie von 1864 bis 1900. - Deutsche Akademie der Landwirtschaftswissenschaften zu Berlin, 5 Bände.

Endnote 2012: Endnote ${ }^{\circledR}$ - Thomson Reuters. URL: http://endnote.com/ (10.10.2012).

GAEDIKE, R. 2005: Zur Klärung einiger Quellen (Datierung, Titeländerungen). - unpublished manuscript, $92 \mathrm{p}$.

Google Books 2012: Google Books. URL: http://books.google.de/ (10.10.2012).

Groll, E. K. 2012: Biographies of the Entomologists of the World : database. version 5.15 - Senckenberg Deutsches Entomologisches Institut. URL: http://sdei.senckenberg.de/biographies/ (10.10.2012).

Groll, E. K. \& Taeger, A. 1996: Über den Aufbau einer entomologischen Datenbank. - Verhandlungen des 14. Internationalen Symposiums über Entomofaunistik in Mitteleuropa (SIEEC), 4.-9. September 1994, München: 331-338.

Hagen, H. A. 1862-1863: Bibliotheca Entomologica. Die Litteratur über das ganze Gebiet der Entomologie bis zum Jahre 1862. - Leipzig, W. Engelmann, Bände 1-2, XII + 566; 512 p.

Horn, W. H. R. \& Schenkling, S. 1928-1929: Index Litteraturae Entomologicae. Serie I: Die WeltLiteratur über die gesamte Entomologie bis inklusive 1863. - Berlin-Dahlem, Selbstverlag W. Horn 1-4: XXI p., 1426 p., 4 Tafeln.

Horn, W. H. R. \& Schenkling, S. 1934: Bitte des Deutschen Entomologischen Institutes um Mitarbeit an der Herstellung einer bibliographischen Kartothek über die gesamte entomologische Literatur der Welt ab 1864. - Arbeiten über morphologische und taxonomische Entomologie aus Berlin-Dahlem, Berlin-Dahlem, 1 (1): 83-84.

Nissen, C. 1951: Die botanische Buchillustration: Ihre Geschichte und Bibliographie. - Stuttgart, Hiersemann.

Nissen, C. 1966-1969: Die zoologische Buchillustration: Ihre Bibliographie und Geschichte. - Stuttgart, Anton Hiersemann, 8 Lief.: 1-666. 
Sherborn, C. D. 1902: Index Animalium sive index nominum quae ab A. D. MDCCLVIII generibus et speciebus animalium imposita sunt. Sectio prima a kalendis januariis, MDCCLVIII usque ad finem decembris, MDCCC. - Cambrigio, e typographio Academico, Part I, LVI + 1195 p.

Sherborn, C. D. 1922-1923: Index Animalium sive index nominum quae ab A. D. MDCCLVIII generibus et speciebus animalium imposita sunt. Sectio secunda a kalendis ianuariis, MDCCCI usque ad finem decembris, MDCCCL. (Bibliography, A-anus). - London, by order of the Trustees, Part II, I-CXXXVI + 1-384.

ZDB-OPAC 2012: : Zeitschriftendatenbank (ZDB) - Staatsbibliothek zu Berlin, Preußischer Kulturbesitz und Deutsche Nationalbibliothek. URL: http://dispatch.opac.d-nb.de/ (10.09.2012).

Zotero 2012: Zotero - Center for History and New Media. URL: http://www.zotero.org/ (10.10.2012).

\section{Author's address:}

Dr. EcKhard K. Groll

Senckenberg Deutsches Entomologisches Institut

Eberswalder Str. 90

15374 Müncheberg

Germany

Email: egroll@senckenberg.de

\section{Subject editor:}

Dr. G. KASPEREK 